\title{
Physicochemical Stability of Natural or Pre-Sweetened Frozen Passion Fruit Juice
}

\author{
Andrea Mara Righetto, Adelaide Beleia ${ }^{*}$ and Sandra Helena P. Ferreira \\ Universidade Estadual de Londrina, Programa de Pós-Graduação em Ciência de Alimentos/TAM, Caixa Postal \\ 6001, CEP 96051-990, Londrina-PR, Brazil.
}

\begin{abstract}
Passion fruit juice, pure and sucrose sweetened $(1: 1, w: v)$, was frozen and stored for 8 months in freezers. The effect of storage time and sucrose addition on physicochemical properties of the juices was evaluated, in the fresh juice, and then every two months in the stored samples. Concentration of soluble solids, organic acids, total and reducing sugars and ascorbic acid, as well as $\mathrm{pH}$ were not affected by storage time. Initially sucrose addition modified the juice color, but not during storage time, while the natural juice became more yellow during storage. $\beta$ carotene content decreased as a function of storage time, $51.3 \%$ in the pure juice and $29.7 \%$ in the sweetened juice.
\end{abstract}

Key words: passion fruit, frozen storage, fruit juices

\section{INTRODUCTION}

Fruit juices are consumed for their characteristic aroma and flavor and are considered a source of vitamins, minerals, soluble and insoluble fibers. Yellow passion fruit (Passiflora edulis var. flavicarpa) has a very acidic pulp, highly intense aroma and flavor and its juice has good acceptability in different markets, pure or in combination with other juices. Storing the fruit is difficult, but the juice may be stored in frozen or pasteurized form. Volatile compounds, responsible for aroma and flavor are very susceptible to heat treatment and during pasteurization up to $35 \%$ of the volatile compounds in the juice may be lost (Kuo et al., 1985). Freezing is well suited for preserving physicochemical and sensory properties of fruit pulps and juices, although it has a higher cost of production and storage (Soler, 1988). Sugars are mostly used for their sweetening property, but also as humectants, plasticizers and flavor enhancers (BeMiller \& Whistler, 1996). In fruitflavored powders for reconstitution of drinks, sugar functions as bulking agent, flavor, aroma and color carrier (Godshall, 1988). The ability of carbohydrates to absorb and retain volatiles during drying processes has been commercially explored and it has important implications and applications in flavor quality of foods (Godshall, 1988; Dziezak, 1988). A presweetened juice needs only dilution for consumption and has the added advantage of the preservative properties of sugar.

The objective of this study was to characterize changes in physico-chemical properties of passion fruit juices, natural or sucrose sweetened, during frozen storage.

\section{MATERIALS AND METHODS}

Yellow passion fruit, characterized by large fruit with the pedicel still attached was bought in bulk quantity from a wholesale market. Fruits were selected, washed, cut in half and pulp with the seeds was scooped out. The juice was processed in a blender, avoiding the breakage of seeds by using the blender intermittently and finished by sieving in a plastic $2 \mathrm{~mm}$ sieve. To sweeten the juice $100 \mathrm{~g}$ of sucrose was added to $100 \mathrm{~g}$ juice (1:1) and dissolution was facilitated

\footnotetext{
* Author for correspondence
} 
by using a blender. The single strength and sweetened juices were vacuum packed in plastic bags in $70 \mathrm{~mL}$ portions, frozen and stored in domestic freezers (average temperature $-18^{\circ} \mathrm{C}$ ). Physicochemical analysis was performed in the fresh juice and every two months in stored samples, up to 8 months of storage.

The total soluble solids were determined in a refractometer ( Carl Zeiss Instruments) at $25^{\circ} \mathrm{C}$, $\mathrm{pH}$ in a digital potentiometer (Alphalab model PA 200), titratable acidity by titration with 0.1 $\mathrm{N}$ sodium hydroxide acidity being expressed as citric acid. Total sugars was determined by the phenol-sulfuric colorimetric method (Dubois et al., 1956) and reducing sugars by Nelson's method (Nelson, 1944). Ascorbic acid was determined by titration with 2,6 dichlorophenolindophenol (AOAC, 1990) and $\beta$-carotene by the classic procedure of open column chromatography (Rodriguez-Amaya et al., 1989). Juice color was measured as reflectance in a colorimeter (Photovolt 575). All analysis were performed in duplicate on three repetitions, for the fresh juice and the four storage times.

Data analysis of physicochemical determinations, as a function of storage time, were subjected to the analysis of variance, mean comparison (Tukey test) and regression, using SAS (Statistical Analysis System Institute, Inc., 1995). The treatments were analyzed separately as sugar addition altered the concentration of the juice components.

\section{RESULTS AND DISCUSSION}

Juice processing yielded $18 \%$ seeds, 50\% skins and $30 \%$ juice, within the average for passion fruit juice extraction (Luh, 1980; Lara et al., 1980). The natural juice froze solid, while the sweetened juice formed a viscous solution. Juice composition was very stable during storage, with the exception of $\beta$-carotene. There was no change for $\mathrm{pH}$ or soluble solids for pure or sweetened juices as a function of storage time. Natural juice had values between 12.8 and $13.2 \%$ for soluble solids, above the minimum of 9\% required in passion fruit juice (SIVP,
1972). Sucrose addition increased the soluble solids to values between 54.7 and $55.6 \%$ (Table 1).

Color is one of the most important attribute of food appearance (McLaren, 1980). Passion fruit juice color varies from yellow to reddishorange and results from the presence of carotenoids. Average reflected wave length for the pure juice was $591 \mathrm{~nm}$ (orange) and from the sweetened juice $582 \mathrm{~nm}$ (orange-yellow), which is typical for passion fruit juice (Lara et al., 1980; Casimir et al., 1978). Sucrose addition altered the color of the juice to orange-yellow but it remained stable during storage, while in the natural juice had a slight and constant change in color during storage. Regression analysis, for the natural juice showed a linear decrease in the average reflected wave length to a lighter color, - $1.4 \mathrm{~nm}$ month $^{-1}\left(\mathrm{r}^{2}=0.966\right)$, during the storage period. Reduction in color intensity could be related to decreasing concentration of $\beta$-carotene and probably because of oxidation of other carotenoids present in the juice. Passion fruit juice contains $\alpha, \beta, \xi$, and $\gamma$ corotene, neurosporene, aurochrome, cryptochrome, lycopene and auroxanathin, with $\xi$-carotene as the principal pigment and $\beta$-carotene as the main source of vitamin A activity (Cecchi \& Rodriguez-Amaya, 1972).

In the natural juice $\beta$-carotene initial concentration was $6 \mu \mathrm{g} / \mathrm{g}$ and there was a linear decrease of $0.34 \mu \mathrm{g}$ month $^{-1}$ of storage $\left(r^{2}=0.848\right)$, for a total reduction of $51.3 \%$ after 8 months. Cecchi, (1978) found $10.9 \mu \mathrm{g} / \mathrm{g}$ of $\beta$ carotene in juice of fresh passion fruit and 1.6 $\mu \mathrm{g} / \mathrm{g}$ in juice of refrigeration stored fruits. Sweetened juice had an initial concentration of $2.7 \mu \mathrm{g} / \mathrm{g}$ and after 8 months $1.9 \mu \mathrm{g} / \mathrm{g}$ or $29.6 \%$ reduction. The sweetened juice had 450 I.U. of vitamin $\mathrm{A} / 100 \mathrm{~g}$ of juice initially and still retained $316 \mathrm{I}$. U./100g of juice after the storage time. It is possible that the sugar played a role in stabilizing the $\beta$-carotene, since that was the only difference between treatments.

Organic acids, total sugars and reducing sugars did not change as a function of storage time in natural or sweetened juices. Ascorbic acid 
varied from 14.9 to $16.1 \mathrm{mg} / 100 \mathrm{~g}$ of natural juice and 7.8 to $8.2 \mathrm{mg} / 100 \mathrm{~g}$ for sweetened juices, due the dilution caused by the sugar addition. In both treatments loses were lower than 5\% during the 8 months of storage. Venning et al., 1989 analyzing kiwi pulp found that total vitamin $\mathrm{C}$ had an average reduction of
$6 \%$ and that $\mathrm{pH}$, titratable acidity and total soluble solids were unaffected by frozen storage for one year, in both deaerated and nondeaerated pulp, at $-18^{\circ} \mathrm{C}$ or lower storage temperature.

Table 1. Physicochemical determinations in frozen passion fruit juices a function of storage time. Treatments were analyzed separately.

\begin{tabular}{lcccccccc}
\hline $\begin{array}{c}\text { Sweetened } \\
\text { samples }\end{array}$ & $\begin{array}{c}\text { Ascorbic } \\
\text { acid } \\
\mathrm{mg} / 100 \mathrm{~g}\end{array}$ & $\begin{array}{c}\beta \text {-carotene } \\
\mu \mathrm{g} / 100 \mathrm{~g}\end{array}$ & $\begin{array}{c}\text { Organic } \\
\text { acids } \%\end{array}$ & Color $\mathrm{nm}$ & $\mathrm{pH}$ & ${ }^{\circ}$ Brix & $\begin{array}{c}\text { Total } \\
\text { sugars } \%\end{array}$ & $\begin{array}{c}\text { Reducing } \\
\text { sugars } \%\end{array}$ \\
\hline Fresh & $8.2 \mathrm{a}$ & 2.8 & 2,3 & 584 & 2.84 & 55.6 & 65.9 & 1.9 \\
2 months & $8.2 \mathrm{a}$ & 2.3 & 2.4 & 584 & 2.89 & 55.3 & 65.5 & 2.1 \\
4 months & $8.1 \mathrm{ab}$ & 2.2 & 2.4 & 583 & 2.80 & 54.7 & 62.5 & 1.9 \\
6 months & $7.9 \mathrm{ab}$ & 2.0 & 2.5 & 581 & 2.79 & 54.7 & 65.4 & 1.9 \\
8 months & $7.8 \mathrm{~b}$ & 1.9 & 2.5 & 581 & 2.81 & 54.7 & 64.1 & 1.8 \\
\hline Natural & & & & & & & & \\
\hline Fresh & 15.4 & $6.0 \mathrm{a}$ & 4.0 & 597 & 2.82 & 13.1 & 8,8 & 3.7 \\
2 months & 16.1 & $5.5 \mathrm{a}$ & 4.1 & 592 & 3.09 & 13.1 & 8.4 & 3.6 \\
4 months & 15.8 & $5.1 \mathrm{~b}$ & 4.2 & 591 & 2.81 & 12.9 & 8.6 & 3.6 \\
6 months & 15.1 & $4.8 \mathrm{~b}$ & 4.2 & 588 & 2.80 & 12.8 & 8.6 & 3.5 \\
8 months & 14.9 & $2.9 \mathrm{c}$ & 4.3 & 585 & 2.83 & 12.7 & 8.3 & 3.5 \\
\hline
\end{tabular}

a-c: numbers with the same letter in the column, by treatment, are not different $\mathrm{p}<0.05 \%$.

\section{CONCLUSIONS}

Soluble solids, organic acids, total and reducing sugars, ascorbic acid content and $\mathrm{pH}$ were not affected by the storage time in both the treatments. Sucrose addition modified the color of the juice, but there was no further color alteration during storage. Pure juice changed color along the storage time, which could be cause by carotenoids degradation. $\beta$-carotene was reduced to $50 \%$ of its initial value in pure juice and to $68 \%$ in the sweetened juice. Analysis of variance of sensory evaluation data for the fresh juices showed no difference for pure or sweetened juices in sweet and passion fruit aromas and for acid and passion fruit flavors, residual flavor was reduced in the sweetened juice. After 8 months of storage, sweetened juice, compared to pure juice, had higher values for all sensory attributes, with the exception of acidity.

\section{RESUMO}

Suco de maracujá, puro ou previamente adoçado com sacarose, 1:1 (p:v), foi congelado e armazenado por 8 meses em congeladores com temperatura de $-18^{\circ} \mathrm{C}$. O efeito de tempo de armazenamento e adição de sacarose sobre propriedades físico-químicas foi avalida inicialmente no suco fresco e a cada dois meses nas amostras congeladas. Concentrações de sólidos solúveis, ácidos orgânicos, açúcares totais e redutores e ácido ascórbico, assim como $\mathrm{pH}$, não foram afetados por tempo de armazenamento. Inicialmente a adição de sacarose alterou a cor do suco, mas esta se manteve durante o armazenamento, enquanto o suco natural alterou a cor para amarelo durante o armazenamento. Concentração de $\beta$-caroteno diminuiu em função do tempo de armazenamento, $51,3 \%$ no suco puro e $29,7 \%$ no suco previamente adoçado. 


\section{REFERENCES}

AOAC (1990) Official methods of analysis, ed. American Association of Official Analytical Chemists. AOAC, Arlington

BeMiller, J. N. \& Whistler, R. L. (1996), Carbohydrates. In- Food Chemistry, ed. O. R. Fennema. Marcel Dekker, Inc., New York, pp. 157-224

Casimir, D. J.; Kefford, J.F.; Whitfield, F. B. (1978), Technology and flavor chemistry of passion fruit pieces and concentrates. Advances in Food Research, 27, 243-281

Cecchi, H. M. (1978), Pigmentos, vitamina A e outras propriedades físicas, químicas e sensoriais de sucos de caju e maracujá. M. S. Dissertation, Universidade Estadual de Campinas, Campinas, Brazil

Cecchi, H. M. \& Rodriguez-Amaya, D. (1978), Carotenóides e valor de vitamina A em suco de maracujá processado. Ciência e Cultura, 33, $72-76$

Dubois, M.; Gilles, K. A.; Hamilton, J. K.; Rebers, P. A.; Smith, F. (1956), Colorimetric method for determination of sugars and related substances. Analytical Chemistry, 28, 350-356

Dziezak, J. D.(1988), Microencapsulation and encapsulated ingredients. Food Technology, 42, n.4, 136-146

Godshall, M. A. (1988), The role of carbohydrates in flavor development. Food Technology, 42, n. 11, 71 - 78

Kuo, M. C.; Chen, S. L.; Wu, C. M.; Chen, C. C. (1985), Changes in volatile components of passion fruit juice as affected by centrifugation and pasteurization. J. Food Sci., 50, 1208-1210.
Lara, J.C. ; Tocchini, R. P. ; Hashizume, T. ; Medina, J. C. (1980), Processamento: produtos, caracterização e utilização. In: Maracujá. ITAL, Campinas, pp.115 -153. (Tropical fruits series).

Luh, B. S. (1980), Tropical fruit beverages. InFruit and vegetable juice processing technology, eds. P. E. Nelson \& D. K. Tressler. Avi publishing, Westport, pp. 344435

McLaren, K. (1980), Food colorimetry. InDevelopments in food colors - 1. ed. J. Walford. Applied Science Publishers, New York, pp. 27 - 45

Nelson, N. (1944), A photometric adaptation of the determination of glucose. Journal Biological Chemistry, 53, 375-379, 1944.

Rodriguez-Amaya, D. B. (1994), Estabilidade de carotenóides durante o armazenamento de alimentos. Campinas, Unicamp, $32 \mathrm{p}$

SAS Institute, Inc. (1995), SAS User's Guide: Statistics.SAS Institute, Inc., Cary

SIPV (1972), Secretaria de inspeção de produtos vegetais. Complementação de padrões de identidade e qualidade para suco, refresco e refrigerante de maracujá. Brasília, Ministério da Agricultura, 29 p.

Soler, M. P. (1988), Industrialização de frutas Campinas, ITAL, 1988. $141 \mathrm{p}$.

Venning, J. A.; Burns, D. J. W.; Hoskin, K. M.; Nguyen, T.; Stec, M. G. H. (1989), Factors influencing the stability of frozen kiwi fruit pulp. J. Food. Sci., 54, 396-400

Received: December 14, 1998; Revised: January 11, 1999; Accepted: May 05, 1999. 